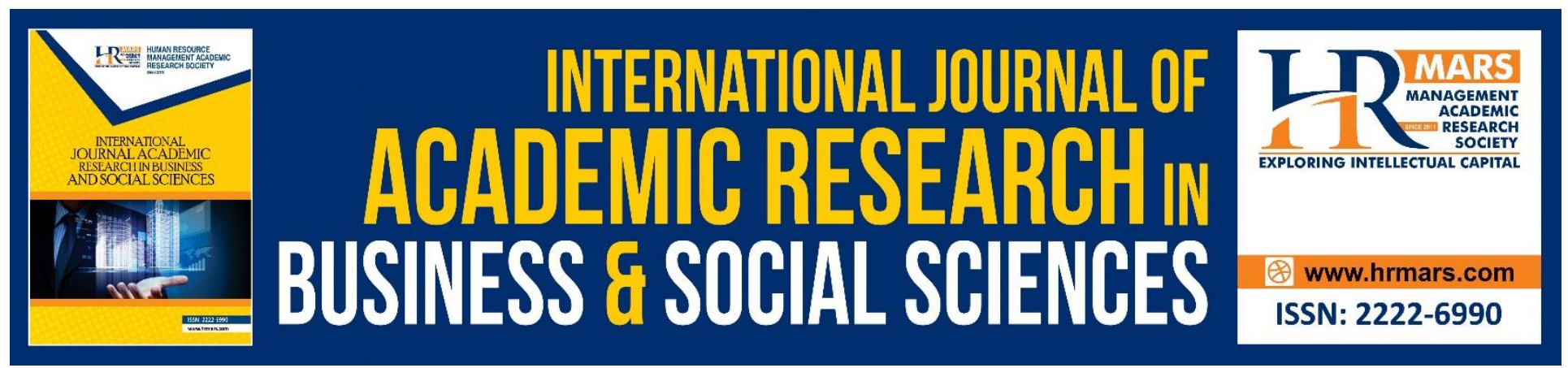

\title{
Neighbour Responsibilities as Informal Care in Malaysia
}

\author{
Nik Norliati Fitri Md Nor
}

To Link this Article: http://dx.doi.org/10.6007/IJARBSS/v10-i10/7739

DOI:10.6007/IJARBSS/v10-i10/7739

Received: 06 July 2020, Revised: 11 August 2020, Accepted: 19 September 2020

Published Online: 08 October 2020

In-Text Citation: (Nor, 2020)

To Cite this Article: Nor, N. N. F. M. (2020). Neighbour Responsibilities as Informal Care in Malaysia. International Journal of Academic Research in Business and Social Sciences. 10(10), 134-142.

Copyright: (c) 2020 The Author(s)

Published by Human Resource Management Academic Research Society (www.hrmars.com)

This article is published under the Creative Commons Attribution (CC BY 4.0) license. Anyone may reproduce, distribute, translate and create derivative works of this article (for both commercial and non-commercial purposes), subject to full attribution to the original publication and authors. The full terms of this license may be seen

at: http://creativecommons.org/licences/by/4.0/legalcode

Vol. 10, No. 10, 2020, Pg. 134 - 142

http://hrmars.com/index.php/pages/detail/IJARBSS

JOURNAL HOMEPAGE

Full Terms \& Conditions of access and use can be found at http://hrmars.com/index.php/pages/detail/publication-ethics 


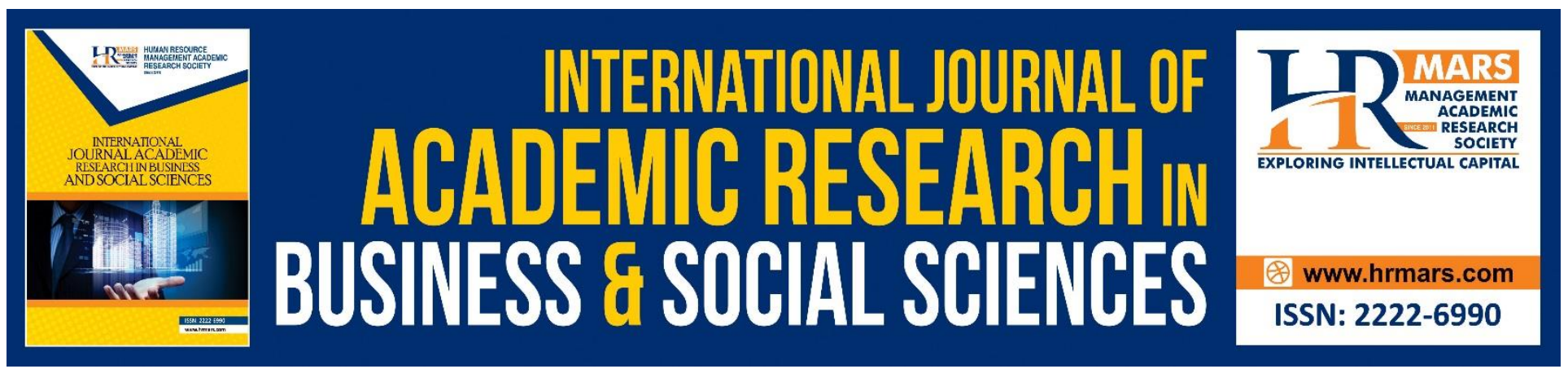

\title{
Neighbour Responsibilities as Informal Care in Malaysia
}

\author{
Nik Norliati Fitri Md Nor \\ Geography Section, School of Distance Education, Universiti Sains Malaysia, 11800 Penang, \\ Malaysia \\ Email: nikfitri@usm.my
}

\begin{abstract}
This article aims to highlight the neighbour responsibilities to take care and always accompany the elderlies after the death of their spouse or after their children have left home. Some research in rural areas found that more children are migrating to the city to look for jobs, to continue their studies, or to follow their husband or wife following their marriage. This situation has made the elderlies suffer from loneliness and experience the empty nest syndrome. However, neighbours always come and help the elderlies to overcome their loneliness. Their neighbours play an important role in helping and accompanying them. Often, in the rural community have highlighted that the attitudes of neighbours are have helped the elderlies to overcome their loneliness and prevented them from experiencing the grief and the empty nest syndrome. This study involves elderlies aged 60 years and older in the rural areas of Pahang, the largest state in Peninsular Malaysia. The research was conducted using a purposive sampling technique. The study result showed that elderlies in the rural areas received attention from neighbours after their children migrated to the city. Neighbours play the role of replacing the children. Neighbours always come to give social support to the elderlies. Support from the neighbours has also contributed to maintain the quality of life of the elderlies in rural areas. This study contributes to the new discovery of the new informal care of the neighbours in the caring of the elderlies in the rural areas.
\end{abstract}

Keywords: Elderly, Neighbours, Loneliness, Well-Being

\section{Introduction}

Neighbours are referred to as people living nearby to someone. In the context of the rural areas, neighbours are those who have close family ties with the elderly. In this study, neighbours are individuals who live near the home of the elderly or who live in the same village as the elderly. Neighbours are those who are expected to help if an elderly is in any difficulties, especially when their children have moved to the city or after the death of their spouse (husband or wife). Neighbours actually play an important role as informal caregivers to the elderlies other than their own family members. 
INTERNATIONAL JOURNAL OF ACADEMIC RESEARCH IN BUSINESS AND SOCIAL SCIENCES Vol. 10, No. 10, 2020, E-ISSN: 2222-6990 @ 2020 HRMARS

Formal caregivers refer to government or private registered charitable entities. However, the informal caregivers for the elderlies refer to family members (children, siblings, relatives) and neighbours. When we think of neighbours, we think of the neighbour who takes care of our home when we are away. Little do we think of them as taking care of the elderlies. In fact, neighbours play a very important role in caring for the elderlies, especially for those living in the rural areas that have been practised since long ago, whether or not we realise it. After their children have moved to the city or to the other places, the neighbours come to take over the role of taking care of the elderly. The term of caring for the elderly such as taking them to health centres when they fall sick, buying their essentials, accompanying them, chatting with them, and accompanying them to do some physical activities such as reciting the Quran, together. Close contacts with neighbours can overcome their feeling of loneliness and their empty nest syndrome (Miao et al., 2019).

A British newspaper reported that the number of elderly people in welfare homes increased because their children and neighbours neglected them (Peev, 2013). Norman Lamb, the British Minister of Care emphasised that the support and attention of neighbours to the elderlies can prevent them from living in welfare homes and ensuring that the elderly can spend the rest of their lives in their own homes. This situation also applies to social support for the elderlies, with their number growing every year; there is a need to guarantee their quality of life. Thus, this article will discuss the role of neighbours in providing support to the elderlies in the rural areas. Neighbours are responsible for helping the elderlies to buy their everyday necessities, to take them for treatment and to accompany them after their children migrated to the city, to find jobs, to continue their studies and to follow with their spouse after getting married. The formatter will need to create these components, incorporating the applicable criteria that follow.

\section{Literature Review}

Neighbours play an important role as informal care for the elderly. Some research has focused on the role of neighbours in taking care of the elderly as informal caregivers. Meanwhile, successful aging refers to a process that requires the active involvement of neighbours, especially in the caring of the elderlies. Help by their neighbours can be in various forms such as helping them to buy their everyday necessities, helping them to settle their utility bills, taking them to treatment centres and accompanying them to mosques. In addition, neighbours can also assist them to clean their home area and taking care of the elderly and accompanying them, especially for the elderly living alone. In this context, accompanying the elderly means doing activities such as gardening and studying the Quran together, often practised by Malay elderlies in rural areas. In cases where they are suffering from chronic illnesses, they need more help and attention as well as emotional support from their neighbours (Waverjin et al., 2017). However, this kind of help also depends on the situation in the neighbourhood itself. Close relationships with neighbours or other communities are key determinants of active aging and the well-being of older people (Fung, 2020). Studies in China found that the role of neighbours as informal caregivers has diminished the traditional caregiving for older people in China (Miao et al., 2019). The responsibility of caring for the elderly is the responsibility of the children, however, with the help and support of neighbours, the role of the child as a source of support for the elderly has been reduced. This also shows that neighbours are becoming the informal caregivers of the elderlies, after their children have moved to the city. 
INTERNATIONAL JOURNAL OF ACADEMIC RESEARCH IN BUSINESS AND SOCIAL SCIENCES Vol. 10, No. 10, 2020, E-ISSN: 2222-6990 @ 2020 HRMARS

\section{Maintaining the Integrity of the Specifications}

The template is used to format your paper and style the text. All margins, column widths, line spaces, and text fonts are prescribed; please do not alter them. You may note peculiarities. For example, the head margin in this template measures proportionately more than is customary. This measurement and others are deliberate, using specifications that anticipate your paper as one part of the entire proceedings, and not as an independent document. Please do not revise any of the current designations.

\section{Methodology}

This study involved 162 elderly Malaysians aged 60 and older in the rural areas of Pahang. Purposive sampling was used to obtain individual respondents who fulfilled the criteria set by the researcher. The respondent characteristics set for this study were Malays aged 60 years and older, in the rural area of Jerantut District, Pahang. For data collection, the survey questionnaire was used because primary data were required to gather information. The information obtained from the questionnaire is a question about the living arrangements that mean with whom they live, the status of health care, who takes them to the health center, who buys necessities, and their activities. Their neighbours responsibilities can avoid feeling lonely and empty nest and make them feel better and well-being. The responses obtained from the questionnaire were analyzed using SPSS using descriptive statistics such as frequencies and correlation analyses among the selected variables to see the relationship the variable had been chosen. Secondary data were obtained through library research such as journals, books, and newspapers.

\section{Results and Discussion}

The result of the study showed that 162 Malay adults were living in the rural areas of Jerantut District, Pahang. From that number, 84 respondents (51.8\%) were elderly males, while 78 respondents $(48.2 \%)$ were elderly females (Table 1$)$. The largest group of respondents was the 60 to 69 years age group (48.8\%) followed by the 70 to 79 year olds (35.8\%). In terms of marital status, most of them categorised themselves as married (67.9\%). Only 1 (0.6\%) of them have never been married, 
INTERNATIONAL JOURNAL OF ACADEMIC RESEARCH IN BUSINESS AND SOCIAL SCIENCES Vol. 10, No. 10, 2020, E-ISSN: 2222-6990 @ 2020 HRMARS

Table 1

Profile of Respondents

\begin{tabular}{lcl}
\hline Characteristics & Frequencies & $\mathbf{( \% )}$ \\
\hline Gender & & \\
Men & 84 & 51.8 \\
Women & 78 & 48.2 \\
Total & 162 & 100.0 \\
Age Group & & \\
60-69 years & 79 & 48.8 \\
70-79 years & 58 & 35.8 \\
80-89 years & 19 & 11.7 \\
90 years and above & 6 & 3.7 \\
Total & 162 & 100.0 \\
Marital Status & & \\
Unmarried & $\mathbf{1}$ & 0.6 \\
Married & $\mathbf{1 1 0}$ & 67.9 \\
Widow & $\mathbf{5 1}$ & 31.5 \\
\hline Total & $\mathbf{1 6 2}$ & $\mathbf{1 0 0 . 0}$ \\
\hline Notes. Data obtained from fieldwor.
\end{tabular}

Notes. Data obtained from fieldwork.

This section discusses the pattern of living arrangements of the elderlies in the study area. Living arrangement refers to where they live (Phillips, 1992). The term "living arrangement" is also used to describe actions or tasks performed by children and family members, directly or indirectly to the elderly to organise and to care for them, particularly in the aspects of the home, their health and medical treatment, nutrition, safety, daily movement and other aspects of social care needed by such groups of people (Glaser, 1997). Older concept of living arrangements also includes quality of life and well-being of the elderlies (Bond \& Corner, 2006). Result obtained in this study showed that $69.7 \%$ of older adults live with their family members (Table 2). Living with family members means that they are living with their spouse, children, daughters-in-law, grandchildren, and siblings. However, 16 of them (9.9\%) were living alone because their spouse had passed away or because their children have migrated to work in the city, or to continue their education or follow the spouse after marriage. Living with spouses in this study refers to those elderlies living with a spouse, either living with a husband or a wife. There were 33 of them (20.4\%). This occurred, especially after the children left home leaving the elderly parents by themselves.

Table 2

Patterns of Living Arrangement of Respondents

\begin{tabular}{llcl}
\hline \multicolumn{2}{l}{ Pattern of living arrangements } & Frequencies & (\%) \\
\hline 1. & Living alone & 16 & 9.9 \\
2. & Living with spouses (husband/ wife) only & 33 & 20.4 \\
3. & Living with family members & 113 & 69.7 \\
\hline Total & $\mathbf{1 6 2}$ & $\mathbf{1 0 0 . 0}$ \\
\hline
\end{tabular}

Notes. Data obtained from fieldwork. 
INTERNATIONAL JOURNAL OF ACADEMIC RESEARCH IN BUSINESS AND SOCIAL SCIENCES Vol. 10, No. 10, 2020, E-ISSN: 2222-6990 @ 2020 HRMARS

This study also found that even though older people were living alone, they still had the support from their children and nearby neighbours. Children living nearby often come to visit their single parents. Children living nearby are expected to take them to the hospital, buy everyday necessities, and even accompany them to the mosque. To respondents living alone, the support from children is important to prevent them from experiencing depression and the empty nest syndrome. Children living far away need to always contact them through the phone because it can overcome their feeling of loneliness when their parents are living alone. Children talking to their parents are often seen as lending social support or emotional support to their parents. The issue of experiencing loneliness among the elderlies is important because the feeling of loneliness among the elderly is closely related to their well-being because loneliness is often seen as the source of emotional stress that is associated with their health problems (Singh \& Kiran, 2013). The feeling of loneliness is subjective and it is a problem related to social isolation, especially when family members and the surrounding community do not give their social support.

In rural areas, neighbours and the surrounding community play an important role in assisting the condition of the elderlies living alone. This is because neighbours and surrounding community are also a major source of care for the elderly, as practised in Hong Kong (Chow, 1992). Neighbours are a source of support for elderly care who live in the rural areas, especially for those living alone and with chronic illnesses (Waverjin et al., 2017).

Studies have shown that neighbours or the surrounding community play the role of replacing the children in caring for the elderly when the children have moved to the city, or for the elderly living alone after the death of their spouse. For example, Respondent 1 (R1), a 71 year old lady living alone after her husband's death and not having children. After the death of the husband, R1 lost her place of trust. Previously, the husband was buying the necessities, took her to health care clinic and accompanied her to the mosque. However, after her husband passed away, her close relationship with her neighbours has caused many neighbours to visit her and helped her to buy everyday essentials such as daily necessities since she had no transportation. Also, in case there is something wrong with her house, she needed help from her neighbours. Her close relationship with her neighbours has caused some neighbours to visit to relieve her from her feeling of loneliness and depression.

To relieve the feeling of loneliness and to close the relationship with neighbours, R1's house was used as a place to study the Quran in the evening, attended by her peers. The class was taught by one of R1's friends and was attended by other R1 friends who lived nearby. In addition to religious knowledge, this activity has prevented R1 from loneliness and the presence of lecturers in the evenings was very enjoyable for her. The role played by her neighbours should be exemplified by all communities and not to leave the elderly alone without their presence. According to Nurizan Yahaya et al. (2013), Malay Muslims in Malaysia have good relationships with neighbours and the surrounding community. Neighbours can help the elderly attend prayers at the mosque, attend wedding invitations, perform their transactions at the bank or other places. Most important is the role of children and family members in reducing loneliness and the empty nest syndrome among the elderly, whether they live with their children or living alone (Teh et al., 2014). Support from neighbours and friends are informal support and the second most important support after family members (Agree \& Glaser, 2009). Support from friends, neighbours and the surrounding community are more commonly practised for the elderly living in the rural areas (Connidis, 2010). 
INTERNATIONAL JOURNAL OF ACADEMIC RESEARCH IN BUSINESS AND SOCIAL SCIENCES Vol. 10, No. 10, 2020, E-ISSN: $2222-6990$ ๑ 2020 HRMARS

In addition, neighbours' support such as accompanying respondents to attend treatment at a hospital or clinic are also viewed as a social support for the Malay elderly in Pahang. Social support for respondents is critical to their well-being and helps the elderly in terms of healthcare. This has made respondents be more positive to healthcare and their attitude with the appointment. The emotional support provided by neighbours, especially to those with chronic illnesses can help relieve their depression and promote active ageing.

In the case of Respondent 2 (R2), an elderly woman, aged 80, she has been receiving assistance from her neighbour to take her to see a doctor or to take her to the hospital. R2 said neighbours sincerely helped her without expecting anything in return, because they used to refuse any money from her for helping her. This situation reflects the support received from neighbours and is a phenomenon commonly seen in rural communities.

For the respondents who are still healthy and can drive on their own, they can go to the hospital easily. However, for some of them, family members and neighbours took them to the hospital or clinic. Also, if the child goes out to work and cannot send them to the treatment centre, then the neighbours are expected to replace the child. Neighbours are expected to send them to the treatment centre, without expecting any payment. It is a prominent social responsibility and is a commonly practised culture especially in the rural areas. Some neighbours help elderly people with chronic illnesses in their daily activities, such as bathing them, feeding them, and dressing them up. According to Waverjin et al. (2017), elderly people with chronic illnesses and those with physical disability who need to live with their spouse and children to get informal support also get help from their neighbours. Neighbours are always there to provide care and help, especially for elderly people who have chronic illnesses and are unable to manage themselves. In this case, Respondent 3 (R3) who was paralysed received social support from family members and neighbours. He lived with his wife and children. However, his son worked in the next village. When his son goes out to work, R3 stayed with his wife who looked after him and taking care of him. R3 has been paralysed for the past three years. However, neighbours always visit him and always help, especially to carry him to the bathroom and so on, as his wife alone could not lift him. The role played by his neighbours is commendable and it can help ease the burden of his wife and family members.

\section{Conclusion}

Community support involves social support from friends and neighbours, especially in helping the elderly living alone. The support can be in the form of visiting them, helping them to buy essentials and taking them to the health centre for treatment and to attend appointments with health professionals. It provides an overview of the social support featured by neighbours. The support from neighbours is an important indicator for relieving loneliness and furthering the well-being of the elderlies, especially those living in the rural areas. The support provided by the community is such that they have to always be on the lookout for the elderlies, especially those who are experiencing loneliness and depression. Social support shown by neighbours such as bringing and accompanying them to receive treatment at a hospital or clinic is particularly important for elderly people living alone and without transportation. The study also highlighted the element of love and the element of goodwill that the neighbours show to the elderly. In addition to the role of family members, there is the role of neighbours in caring for the displaced elderlies and helping them with their health care. This study has also contributed to the understanding on the role of neighbours who are expected to help those elderlies who are single widow or widower and childless. Support from communities like 
INTERNATIONAL JOURNAL OF ACADEMIC RESEARCH IN BUSINESS AND SOCIAL SCIENCES

Vol. 10, No. 10, 2020, E-ISSN: 2222-6990 @ 2020 HRMARS

neighbours has given a new dimension to the importance of community living and the role of neighbours in ensuring the well-being of the elderlies. Neighbourhood concerns that are often highlighted in the rural community have helped the well-being of the elderly to prevent them from experiencing loneliness and the empty nest syndrome. This study hopes that the knowledge it provides will contribute to the understanding the new responsibilities of neighbours to care for, to help and to assist the elderly people and at the same time, manifesting the well-being of the elderly people in the rural areas.

\section{References}

Allen, I., Hogg, D., \& Peace, S. M. (1992). Elderly people: Choice, participation and satisfaction. London: Policy Studies Institute.

Bond, J., \& Corner, L. (2006). The future of well-being: Quality of life of older people in the twentyfirst century. In J. A., Vincent, C. R. Phillipson, \& M. Downer, M. (Eds.). The future of old age (pp. 154-160). London: Sage Publications.

Chow, N. W. S. (1992). Hong Kong: Community care for elderly people. In Phillips, D. R. (Ed.). Ageing in East and South-East Asia (pp. 65-76). London: Edward Arnorld:

Connidis, I. A. (2010). Family ties and aging (2nd ed.). Newbury Park, CA: Pine Forge Press.

Fung, J. C. (2020). Place familiarity and community ageing with place in urban neighbour. Advances in $21^{\text {st }}$ Century Human Settlements. DOI: 10.1007/978-981-13-7048-9_8

Glaser, K. (1997). The living arrangements of elderly people. Reviews in Clinical Gerontology. 7(1), 6372. DOI: https://doi.org/10.1017/S0959259897000075

Miao, J., Wu, X., \& Sun, X. (2019). Neighborhood, social cohesion, and the Elderly's depression in Shanghai. Social Science and Medicine, 229, 134-143. Retrieved from https://doi.org/10.1016/j.socscimed. 2018.08.022

Peev, G. (2013). 'Family neglect' forcing elderly into care homes, says minister as he warns old people face 'dismal existence', Daily Mail. Retrieved from https://www.dailymail.co.uk/news/ article2255615/Families-neighbours-stop-elderly-enduring-dismal-existence-warns-CareMinister.html

Phillips, D. (1992). East and South-east Asia: Issues of ageing in the region. In D. R. Phillips, (Ed). Ageing in East and South-east Asia (pp. 1-21). London: Edward Arnold.

Singh, B., \& Kiran, U. V. (2013). Loneliness among elderly women. International Journal of Humanities and Social Science Invention, 2(2), 10-14.

Teh, J. K. L., Tey, N. P., \& Ng, S. T. (2014). Family support and loneliness among older persons in multiethnic Malaysia. The Scientific World Journal. 2014:654382, 1-11.

Waverijn, G., Heijmans, M., \& Groenewegen, P.P. (2017). Neighbourly support of people with chronic illness: Is it related to neighbour social capital? Social Science and Medicine, 173, 110-117. DOI: 10.1016/j.socscimed.2016.12.004.

Zhang, J., Zhang, J., Zhou, M., and Yu, N. X. (2018). Neighborhood characteristics and older adults' well-being: The roles of sense of community and personal resilience. Social Indicators Research, 137(3), 949-963. 
INTERNATIONAL JOURNAL OF ACADEMIC RESEARCH IN BUSINESS AND SOCIAL SCIENCES Vol. 10, No. 10, 2020, E-ISSN: 2222-6990 @ 2020 HRMARS

Dr. Nik Norliati Fitri Md Nor is a Senior Lecturer in Geography Section, School of Distance Education, Universiti Sains Malaysia (USM), Penang. Areas of study are Ageing Population and Demography. 